\title{
Evaluasi Kesesuaian Lingkungan Berdasarkan Penampilan Produksi Empat Bangsa Sapi pada Ketinggian Berbeda di Provinsi Lampung
}

\author{
(ENVIRONMENTAL SUITABILITY EVALUATION BASED ON THE PERFORMANCE \\ PRODUCTION FOUR BREED CATTLES ON SOME DIFFERENT ALTITUDES \\ IN LAMPUNG PROVINCE)
}

\author{
Nandari Dyah Suretno ${ }^{1^{*}}$, Bagus Priyo Purwanto ${ }^{2 *}$, \\ Rudy Priyanto ${ }^{3}$, Iman Supriyatna ${ }^{4}$ \\ ${ }^{1}$ Mahasiswa Sekolah Pascasarjana, \\ Program Studi Ilmu dan Teknologi Peternakan \\ Fakultas Peternakan, Institut Pertanian Bogor. \\ Jl. Rasamala Kampus IPB Darmaga Bogor 16680 \\ ${ }^{2}$ Direktorat Diploma IPB, Jl. Kumbang No 14 Bogor \\ $1^{1^{2 *}}$ Corresponding author: Telp 082231826087, 08121100162 \\ E-mail : nandari.dyah@yahoo.co.id, bpp030560@yahoo.com \\ ${ }^{3}$ Laboratorium Ilmu Produksi Ternak Ruminansia Besar \\ Fakultas Peternakan, IPB. \\ Jl. Rasamala Kampus IPB Darmaga Bogor 16680 \\ E-mail : rd.priyanto@gmail.com \\ ${ }^{4}$ Departemen Klinik Reproduksi Patologi, \\ Fakultas Kedokteran Hewan, IPB \\ Jl. Agatis Kampus IPB Dramaga, Bogor, Jawa Barat, Indonesia 16680 \\ Email:iman_sprtn@yahoo.com
}

\begin{abstract}
ABSTRAK
Sapi bali mempunyai kemampuan termoregulasi yang lebih baik dibandingkan dengan sapi peranakan ongole di dataran rendah. Sapi simental atau limousin terbiasa hidup di daerah dengan suhu udara yang dingin dan tatalaksana pemeliharaan intensif. Berdasarkan hal tersebut maka tujuan penelitian ini adalah mengetahui kemampuan produksi sapi bali, sapi peranakan ongole, sapi peranakan limousin, dan peranakan simental pada beberapa ketinggian tempat dan musim yang berbeda di Provinsi Lampung. Materi yang digunakan adalah sapi betina dewasa: yaitu sapi bali 82 ekor, sapi peranakan ongole 138 ekor, sapi peranakan limousin 54 ekor, dan sapi peranakan simental 32 ekor. Peubah yang diamati untuk respons produksi adalah tinggi badan, lingkar dada, dan Body Condition Score (BCS). Penelitian ini menggunakan Rancangan Acak Lengkap. Hasil penelitian menunjukkan bahwa berdasarkan ukuran tubuh (tinggi dan lingkar dada) serta BCS, sapi bali cocok dikembangkan di dataran rendah. Sapi PO mempunyai ukuran tubuh sama pada ketiga ketinggian tempat namun BCS terbaiknya di dataran tinggi. Sapi peranakan limousin ternyata penampilan produksi terbaiknya baik musim hujan maupun musim kemarau di dataran rendah. Sementara sapi peranakan simental cocok dikembangkan di dataran rendah dan dataran tinggi.
\end{abstract}

Kata-kata kunci: ketinggian tempat; musim; tinggi badan; lingkar dada; BCS

\begin{abstract}
Each cattle breed can grow optimally at suitable environmental condition. bali cattle has better thermoregulation ability in incompaing with-ongole crossbreed cattle in lowland. Simental or limousin cattle is from temperate zone with cold temperature area and intensive breeding management. Based on those considerations, this research aimed was to investigate the production performance of bali cattle, ongole crossbreed, limousine crossbreed and simental crossbreed cattle at different altitudes and seasons
\end{abstract}


in Lampung Province. Research used adult female cattle consisting of 82 bali cattle, 138 ongole crossbreed cattle, 54 limousin crossbreed cattle and 32 simental crossbreed cattle. The observed variables as production response were body height, chest size and Body Condition Score (BCS). Data was then analyzed using Randomized Complete Design. Based on body size (height and chest circumference) and BCS, it can be concluded that the Bali cattle suitable to be developed in the lowlands, ongole crossbreed cows in the highlands, limousine crossbreed in the lowlands and simmental crossbreed suitable to be developed in both the lowlands and highlands.

Keywords: altitude; season; body height; chest size; BCS

\section{PENDAHULUAN}

Faktor utama yang memengaruhi produktivitas (produksi dan reproduksi) ternak dicerminkan oleh penampilannya (performans), sedangkan penampilan ternak merupakan manifestasi pengaruh genetik (G) dan lingkungan (L) secara bersama-sama. Faktor genetik menentukan kemampuan produksi dan reproduksi, sedangkan lingkungan merupakan pendukung supaya ternak mampu berproduksi sesuai dengan kemampuannya. Ternak dengan sifat genetik baik tidak akan mengekspresikan potensi genetiknya tanpa didukung oleh lingkungan yang menunjang. Bahkan telah diketahui bahwa dalam membentuk penampilan, lingkungan memiliki persentase lebih tinggi dibandingkan dengan genetik, yaitu 70\% lingkungan dan $30 \%$ genetik.

Faktor lingkungan adalah pakan, pengelolaan, perkandangan, penyakit dan iklim (mikro maupun makro). Pengaruh tidak langsung dari lingkungan adalah ketersediaan pakan, tingginya serat kasar, perkandangan dan penyakit. Iklim merupakan faktor lingkungan yang langsung berpengaruh pada kehidupan ternak, namun iklim juga berpengaruh tidak langsung melalui pengaruhnya terhadap faktor lingkungan yang lain (pakan dan kesehatan). Iklim merupakan faktor penentu ciri khas dan pola hidup dari suatu ternak. Ada empat faktor iklim utama yang berinteraksi yaitu: suhu udara, kelembapan, radiasi matahari dan kecepatan angin.

Pertumbuhan populasi sapi potong di Indonesia selama 2013-2015 mencapai 8\% per tahun atau rataan pertambahan 1,404 juta ekor setiap tahunnya. Pertumbuhan populasi sapi potong di provinsi Lampung selama tahun 20132015 mencapai 2,18\% (Ditjen PKH Kementan 2015).

Hasil pendataan sapi potong, sapi perah dan kerbau pada tahun 2011 menunjukkan bahwa populasi ternak sapi potong di Provinsi Lampung sebanyak 742.776 ekor menempati urutan pertama di Pulau Sumatera. Bangsa sapi yang paling banyak ditemui di Provinsi Lampung adalah sapi PO (Bos indicus), sapi bali (Bos javanicus), serta sapi peranakan limousin dan sapi peranakan simental (Bos taurus) dengan populasi berturut-turut 408.954 ekor, 186.712 ekor, dan 42.883 ekor atau sebesar 55,06\%; $25,14 \%$ dan 5,77\% (BPS 2011). Sapi-sapi tersebut tersebar di seluruh wilayah Provinsi Lampung yang secara topografi bervariasi karena ketinggian tempat dari permukaan laut di Provinsi Lampung adalah mulai dari 1-512 mdpl (BPS 2015).

Penilaian produktivitas ternak dapat dilihat melalui BCS. Rutter (2000) dan Ditjennak (2010) membagi ternak sapi potong menjadi lima kategori berdasarkan BCS yaitu sangat kurus, kurus, sedang, gemuk dan sangat gemuk. Indikator lainnya dapat dilihat berdasarkan parameter tubuh ternak tersebut. Parameter tubuh yang sering digunakan dalam menilai produktivitas antara lain lingkar dada, tinggi badan dan panjang badan. Bobot badan juga merupakan indikator penilaian produktivitas dan keberhasilan manajemen peternakan (Ulatus et al., 2001).

Menurut Sugama dan Budiari (2012) skor kondisi tubuh sapi bali meningkat dari 2,4 menjadi 3-4. Body Condition Score sapi PO skala 1-5 adalah 3,35 (Haryoko dan Suparman, 2009), sapi limousin-hereford dan simentalhereford umur tiga tahun adalah 6,16 dan 5,38 (Arango et al. 2002). Lingkar dada sapi bali poel 1 , poel 2, poel 3, dan poel 4 secara berurutan sebesar 136,30 cm; 135,75 cm; 141,35 cm dan $142,75 \mathrm{~cm}$ (Ni'am et al., 2012); sapi PO 159,43 cm (Haryoko dan Suparman, 2009) dan 175,18 \pm 9,26 (Paputungan et al., 2013); sapi peranakan limousin $167,20 \pm 14,07 \mathrm{~cm}$ dan peranakan simental 167,60 $\pm 9,47 \mathrm{~cm}$ (Trifena et al., 2011). Tinggi badan sapi bali poel 1, poel 2, poel 3 dan poel 4 secara berurutan adalah $106,6 \mathrm{~cm} ; 106,8$ cm, 109, $8 \mathrm{~cm}$ dan 111,5 cm (Ni'am et al. 2012); sapi PO $124,25 \pm 2,00 \mathrm{~cm}$ (Putra et al., 2016); sapi peranakan limousin $126,55 \pm 5,52 \mathrm{~cm}$ dan 
peranakan Simental 125,15 $\pm 6,25 \mathrm{~cm}$ (Trifena et al., 2011).

Sapi bali mempunyai kemampuan termoregulasi lebih baik dibandingkan dengan sapi PO di dataran rendah. Sapi simental atau limousin adalah sapi yang berasal dari daerah sedang (temperate zone), terbiasa hidup di daerah dengan temperatur udara yang dingin dan tatalaksana pemeliharaan yang intensif (Astuti et al., 2002). Karena perbedaan respons terhadap lingkungan tersebut maka tujuan penelitian ini adalah untuk mengetahui kemampuan produksi sapi bali, sapi PO, sapi peranakan limousine, dan sapi peranakan simental pada beberapa ketinggian tempat yang berbeda di Provinsi Lampung.

\section{METODE PENELITIAN}

Penelitian dilaksanakan dua kali yaitu bulan Desember 2013 hingga Februari 2014 mewakili musim penghujan dan bulan Juli hingga September 2014 mewakili musim kemarau. Lokasi penelitian adalah peternakan sapi rakyat pada tiga kabupaten di Provinsi Lampung, yaitu Kabupaten Lampung Tengah mewakili dataran rendah (0-100 mdpl), Kabupaten Pesawaran mewakili dataran menengah (100-250 mdpl), dan Kabupaten Lampung Barat mewakili dataran tinggi ( $>400$ $\mathrm{mdpl})$. Sapi yang digunakan adalah sapi betina dewasa, antara lain sapi bali sebanyak 82 ekor, sapi peranakan ongole 138 ekor, sapi peranakan limousin 54 ekor, dan sapi peranakan simental 32 ekor. Umur sapi-sapi tersebut adalah 2-6 tahun, dengan cara pemeliharaan dikandangkan.

\section{Metode Penelitian}

Peubah yang diamati adalah respons produksi seperti lingkar dada, tinggi badan dan BCS. Pengukuran lingkar dada dan tinggi badan dilakukan saat sapi berdiri tegak. Lingkar dada diukur dengan pita pengukur pada dada tepat di belakang kaki depan (Paputungan et al., 2013; Ige et al., 2015). Pengukuran tinggi badan dilakukan dengan cara mengukur tinggi pundak bagian belakang punuk/gumba (Savanon et al., 2011; Ige et al., 2015). Body Condition Score diukur berdasarkan sistem skoring menurut Rutter et al. (2000) yaitu BCS 1: sangat kurus, BCS 2: kurus, BCS 3: sedang, BCS 4: gemuk, dan BCS 5: sangat gemuk.

\section{Rancangan Percobaan}

Pengaruh ketinggian terhadap kemampuan produksi empat bangsa sapi (sapi bali, PO, peranakan limousin, dan peranakan simental) menggunakan rancangan acak lengkap dengan tiga taraf perlakuan yaitu ketinggian tempat. Data yang diperoleh kemudian dianalisis dengan sidik ragam dan jika ada perbedaan yang nyata diuji lanjut menggunakan Uji Jarak Berganda Duncan untuk mengetahui beda antar perlakuan (Steel dan Torrie, 1993). Adapun model umum yang dikemukakan dalam penelitian ini adalah: $\mathrm{Y}_{\mathrm{ij}}=\mu+\alpha_{\mathrm{i}}+\varepsilon_{\mathrm{ij}}$. Dalam hal ini $\mathrm{i}=1,2,3 ; \mathrm{j}=1,2, \ldots . . \mathrm{n} ; \mathrm{Yij}=$ hasil pengamatan pada perlakuan ke-i, ulangan ke-j; $\mu=$ nilai tengah umum; $\alpha_{i}=$ pengaruh ketinggian tempat ke-i; $\varepsilon_{\mathrm{ij}}=$ pengaruh galat percobaan pada perlakuan ke-i dan ulangan ke-j.

\section{HASIL DAN PEMBAHASAN}

\section{Keadaan Umum Peternakan di Lokasi Penelitian}

Rataan kepemilikan ternak pada ketiga ketinggian tempat, disajikan pada Tabel 1. Rataan kepemilikan ternak tertinggi adalah Lampung Tengah 3,59 ekor/peternak dan terendah adalah Pesawaran yaitu 1,89 ekor/ peternak. Kepemilikan yang masih sangat rendah ini karena tujuan pemeliharaannya adalah sebagai sampingan saja di samping digunakan sebagai tabungan dan dimanfaatkan tenaganya untuk membantu peternak dalam pengelolaan usaha pertaniannya. Selain itu peternakan merupakan usaha yang dikelola oleh rumah tangga petani, dengan modal, tenaga kerja, dan manajemen yang terbatas (Hadi dan Ilham, 2002).

Kepemilikan ternak yang tinggi di Lampung Tengah disebabkan oleh populasi ternak sapi potong di Provinsi Lampung tertinggi ada di Lampung Tengah yaitu 288.449 ekor (38,83\%). Populasi sapi potong di Lampung Barat sebesar 18.527 ekor $(2,49 \%)$, dan untuk Pesawaran populasinya 17.916 ekor (2,41\%) (BPS 2011 Ditjen PKH). Populasi sapi potong yang tinggi di Lampung Tengah disebabkan ketersediaan pakan dari limbah tanaman pangan yang lebih banyak. Pola pemanfaatan lahan sebagai lahan tanaman pangan tertinggi di Lampung Tengah sebesar 16,02\% disusul Pesawaran (7,56\%) dan terendah di Lampung Barat (4,26\%) (BPS 2015).

Pakan hijauan yang diberikan di semua 
kabupaten di Lampung pada musim hujan adalah rumput gajah dengan tambahan dedak atau onggok. Namun, saat musim kemarau pakan yang diberikan berupa rumput alam, jerami padi, dan jerami jagung. Jenis pakan yang diberikan terhadap empat bangsa sapi pada tiga ketinggan tempat, disajikan pada Tabel 2.

Jumlah pemberian pakan tertinggi yang disajikan pada Tabel 3 adalah pakan yang diberikan pada sapi PO di Lampung Barat. Jumlah pakan yang banyak tersebut diharapkan sapi PO di Lampung Barat mempunyai performans produktivitas yang lebih baik. Rataan pemberian pakan terendah adalah pakan yang diberikan pada sapi bali, hal ini menunjukkan bahwa sapi bali mampu berkembang pada kondisi pakan yang sulit. Sementara itu rataan pakan yang diberikan di Pesawaran paling rendah di antara kedua daerah lainnya. Dengan kondisi iklim yang hampir sama dengan di Lampung Tengah dikhawa- tirkan jumlah pakan tersebut tidak cukup untuk pertumbuhan dan hanya cukup untuk mengatasi stress karena lingkungan.

\section{Keadaan Cuaca Lokasi Penelitian}

Keadaan cuaca pada saat penelitian yaitu pada musim hujan dan kemarau disajikan pada Tabel 4. Secara umum dapat dilihat bahwa di daerah dataran tinggi mempunyai Ta dan THI paling rendah baik pada musim hujan maupun musim kemarau. Sesuai hasil penelitian Nuriyasa et al. (2015) yang melaporkan bahwa suhu udara di dataran tinggi $\left(24,89^{\circ} \mathrm{C}\right)$ lebih rendah dibanding dataran sedang $\left(26,03^{\circ} \mathrm{C}\right)$ dan dataran rendah $\left(28,42{ }^{\circ} \mathrm{C}\right)$. Lebih lanjut dilaporkan bahwa THI di dataran tinggi $(68,04)$ lebih rendah dibanding dataran sedang $(70,06)$ dan dataran rendah $(73,24)$.

Dataran Tinggi memiliki $\mathrm{RH}$ yang relatif lebih tinggi dibandingkan kedua daerah lainnya pada musim kemarau, namun dibawah dataran

Tabel 1. Rataan kepemilikan ternak sapi pada tiga ketinggian tempat berbeda di Lampung

\begin{tabular}{lcccc}
\hline Bangsa Sapi & $\begin{array}{c}\text { Lampung Tengah } \\
\text { (ekor/peternak) }\end{array}$ & $\begin{array}{c}\text { Pesawaran } \\
\text { (ekor/peternak) }\end{array}$ & $\begin{array}{c}\text { Lampung Barat } \\
\text { (ekor/peternak) }\end{array}$ & Rataan \\
\hline Sapi bali & 4,60 & 1,75 & 2,00 & 2.78 \\
Peranakan ongole & 2,25 & 2,14 & 2,57 & 2,32 \\
Peranakan limousin & 3,50 & 2,00 & 2,00 & 2,50 \\
Peranakan simental & 4,00 & 1,67 & 3,25 & 2,97 \\
Rataan & 3,59 & 1,89 & 2,46 & \\
\hline
\end{tabular}

Tabel 2. Jenis pakan sapi yang diberikan pada tiga ketinggian tempat pemeliharaan di Lampung

\begin{tabular}{|c|c|c|c|}
\hline Bangsa Sapi & Lampung Tengah & Pesawaran & Lampung Barat \\
\hline Sapi bali & $\begin{array}{l}\text { Rumput gajah, } \\
\text { rumput alam, } \\
\text { onggok, jerami } \\
\text { padi }\end{array}$ & $\begin{array}{l}\text { Rumput gajah, } \\
\text { rumput alam, } \\
\text { jerami jagung, } \\
\text { jerami padi }\end{array}$ & $\begin{array}{l}\text { Rumput gajah, } \\
\text { rumput alam, } \\
\text { limbah sayuran }\end{array}$ \\
\hline Peranakan ongole & $\begin{array}{l}\text { Rumput gajah, } \\
\text { rumput alam, } \\
\text { setaria, dedak, } \\
\text { jerami padi }\end{array}$ & $\begin{array}{l}\text { Rumput gajah, } \\
\text { rumput alam, } \\
\text { dedak, jerami } \\
\text { padi }\end{array}$ & $\begin{array}{l}\text { Rumput gajah, } \\
\text { rumput raja, } \\
\text { rumput alam, } \\
\text { dedak }\end{array}$ \\
\hline Peranakan limousin & $\begin{array}{l}\text { Rumput gajah, } \\
\text { dedak, onggok, } \\
\text { jerami padi }\end{array}$ & $\begin{array}{l}\text { Rumput gajah, } \\
\text { rumput alam, } \\
\text { dedak, kulit singkong, } \\
\text { jerami padi }\end{array}$ & $\begin{array}{l}\text { Rumput gajah, } \\
\text { rumput raja, } \\
\text { dedak }\end{array}$ \\
\hline Peranakan simental & $\begin{array}{l}\text { Rumput gajah, } \\
\text { rumput alam, } \\
\text { dedak, onggok, } \\
\text { jerami padi }\end{array}$ & $\begin{array}{l}\text { Rumput gajah, } \\
\text { rumput alam, } \\
\text { onggok, jerami } \\
\text { padi }\end{array}$ & $\begin{array}{l}\text { Rumput gajah, } \\
\text { rumput raja, } \\
\text { dedak }\end{array}$ \\
\hline
\end{tabular}


menengah pada musim hujan. Kelembapan terendah ada di dataran rendah pada musim hujan dan dataran menengah pada musim kemarau.

\section{Tinggi Badan}

Keempat bangsa sapi pada tiga ketinggian tempat mempunyai tinggi badan yang sama $(\mathrm{P}>0,05)$ pada awal penelitian yaitu pada musim hujan (Tabel 5). Hasil ini menunjukkan bahwa ketersediaan pakan di musim hujan pada ketiga ketinggian tempat cukup untuk pertumbuhan keempat bangsa sapi.

Delapan bulan kemudian yaitu pada musim kemarau, ketinggian tempat memengaruhi $(\mathrm{P}<0,05)$ tinggi badan sapi bali dan sapi peranakan limousin. Tinggi badan sapi bali di Pesawaran sama dengan di Lampung Tengah tetapi lebih pendek dibandingkan tinggi badan sapi bali di Lampung Barat. Suhu udara yang tidak jauh berbeda di Pesawaran dan di Lampung Tengah memberikan pengaruh yang sama pada sapi bali. Suhu udara pada kedua daerah ini berada di atas comfort zone bagi ternak tropik terutama pada siang hari, sehingga energi yang diperoleh dari pakan digunakan untuk menghilangkan stress akibat suhu lingkungan, dan menurut Mursa (2011) comfort zone bagi ternak tropik berkisar antara $10-27^{\circ} \mathrm{C}$.

Ketinggian tempat juga memengaruhi tinggi badan sapi peranakan limousin, tinggi badan sapi ini di Lampung Barat sama dengan di Pesawaran tetapi lebih pendek dibandingkan di Lampung Tengah. Sebagai ternak hasil silangan dari sapi daerah beriklim sedang, ternyata suhu yang rendah di dataran tinggi tidak membuat pertumbuhan yang maksimal bagi sapi ini. Kemungkinan ini terjadi karena jumlah pakan yang diberikan di Lampung Tengah $(57,25 \mathrm{~kg})$ cukup untuk membantu sapi peranakan limousin menghadapi stress lingkungan. Pakan berupa rumput bagi sapi dewasa umumnya diberikan sebanyak 10\% dari

Tabel 3. Jumlah pemberian pakan sapi pada tiga ketinggian tempat di Lampung

\begin{tabular}{lcccc}
\hline Bangsa Sapi & $\begin{array}{c}\text { Lampung Tengah } \\
\text { (kg/ekor) }\end{array}$ & $\begin{array}{c}\text { Pesawaran } \\
\text { (kg/ekor) }\end{array}$ & $\begin{array}{c}\text { Lampung Barat } \\
\text { (kg/ekor) }\end{array}$ & Rataan \\
\hline Sapi bali & 41,33 & 39,45 & 40,00 & 40,26 \\
Peranakan ongole & 60,63 & 44,19 & 65,35 & 56.72 \\
Peranakan limousin & 57,25 & 50,75 & 57,29 & 55.10 \\
Peranakan simental & 55,00 & 52,67 & 60,00 & 55,89 \\
Rataan & 53,55 & 46,77 & 55,66 & \\
\hline
\end{tabular}

Tabel 4. Keadaan cuaca dan Temperature Humidity Index THI di lokasi penelitian (Provinsi Lampung) pada musim hujan dan musim kemarau*.

\begin{tabular}{lcccccr}
\hline \multirow{2}{*}{ Unsur cuaca } & \multicolumn{3}{c}{ Musim Hujan } & \multicolumn{3}{c}{ Musim Kemarau } \\
\cline { 2 - 7 } & $\begin{array}{c}\text { Dataran } \\
\text { Rendah }\end{array}$ & $\begin{array}{c}\text { Dataran } \\
\text { Menengah }\end{array}$ & $\begin{array}{c}\text { Dataran } \\
\text { Tinggi }\end{array}$ & $\begin{array}{c}\text { Dataran } \\
\text { Rendah }\end{array}$ & $\begin{array}{c}\text { Dataran } \\
\text { Menengah }\end{array}$ & $\begin{array}{c}\text { Dataran } \\
\text { Tinggi }\end{array}$ \\
\hline Ketinggian & $35-50$ & $120-136$ & $494-500$ & $35-50$ & $120-136$ & $494-500$ \\
tempat (mdpl) & & & & & & \\
Ta ( ${ }^{\circ}$ C) & $29,45 \pm 0,86$ & $27,27 \pm 0,72$ & $23,18 \pm 0,39$ & $29,30 \pm 1,74$ & $30,12 \pm 1,10$ & $24,54 \pm 1,74$ \\
RH (\%) & $78,60 \pm 6,10$ & $81,43 \pm 3,66$ & $81,18 \pm 4,15$ & $66,45 \pm 13,38$ & $63,77 \pm 8,81$ & $68,50 \pm 7,33$ \\
Va(m/s) & $0,75 \pm 0,34$ & $0,82 \pm 0,42$ & $1,22 \pm 0,50$ & $0,48 \pm 0,60$ & $0,23 \pm 0,26$ & $1,00 \pm 1,44$ \\
Im(lux) & $1,98 \pm 1,30$ & $2,55 \pm 1,26$ & $3,14 \pm 1,29$ & $2,71 \pm 2,57$ & $3,93 \pm 6,99$ & $2,41 \pm 1,49$ \\
THI & $80,82 \pm 2,82$ & $78,60 \pm 1,19$ & $71,94 \pm 4,20$ & $79,07 \pm 1,58$ & $79,87 \pm 1,23$ & $72,53 \pm 4,36$ \\
\hline
\end{tabular}

Keterangan : * Suretno et al. (2016)

$\mathrm{Ta}\left({ }^{\circ} \mathrm{C}\right)=$ suhu lingkungan dalam derajat Celcius; $\mathrm{RH}(\%)=$ kelembapan relatif dalam persentase; $\mathrm{Va}(\mathrm{m} / \mathrm{s})=$ kecepatan angin dalam satuan meter per detik; Im (lux)= Intensitas radiasi cahaya matahari dalam lux; THI= Temperature Humidity Index 
Tabel 5. Tinggi badan sapi (cm) di tiga ketinggian tempat yang berbeda di Lampung

\begin{tabular}{lcccccc}
\hline Bangsa Sapi & $\mathrm{n}$ & Lampung Tengah & $\mathrm{n}$ & Pesawaran & $\mathrm{n}$ & Lampung Barat \\
\hline Musim Hujan & & & & & & \\
Sapi bali & 13 & $110,77 \pm 4,92^{\mathrm{a}}$ & 25 & $106,88 \pm 4,67^{\mathrm{a}}$ & 3 & $112,33 \pm 4,04^{\mathrm{a}}$ \\
Peranakan ongole & 14 & $124,00 \pm 4,26^{\mathrm{a}}$ & 27 & $124,81 \pm 5,34^{\mathrm{a}}$ & 28 & $123,54 \pm 5,39^{\mathrm{a}}$ \\
Peranakan Limousin & 8 & $131,38 \pm 8,00^{\mathrm{a}}$ & 5 & $127,40 \pm 4,83^{\mathrm{a}}$ & 14 & $124,86 \pm 5,37^{\mathrm{a}}$ \\
Peranakan Simental & 7 & $127,0 \pm 10,79^{\mathrm{a}}$ & 3 & $116,00 \pm 4,00^{\mathrm{a}}$ & 6 & $123,60 \pm 7,57^{\mathrm{a}}$ \\
\hline Musim Kemarau & & & & & & \\
Sapi bali & 13 & $112,92 \pm 5,65^{\mathrm{ab}}$ & 25 & $108,56 \pm 4,66^{\mathrm{b}}$ & 3 & $114.33 \pm 2.52^{\mathrm{a}}$ \\
Peranakan ongole & 14 & $125,79 \pm 5,42^{\mathrm{a}}$ & 27 & $126,11 \pm 5,00^{\mathrm{a}}$ & 28 & $123.86 \pm 5.08^{\mathrm{a}}$ \\
Peranakan Limousin & 8 & $131,63 \pm 6,76^{\mathrm{a}}$ & 5 & $128,60 \pm 5,77^{\mathrm{ab}}$ & 14 & $125.29 \pm 4.78^{\mathrm{b}}$ \\
Peranakan Simental & 7 & $127,86 \pm 10,12^{\mathrm{a}}$ & 3 & $121,33 \pm 4,04^{\mathrm{a}}$ & 6 & $125.60 \pm 7.06^{\mathrm{a}}$ \\
\hline
\end{tabular}

Keterangan: Superskrip huruf yang berbeda pada baris yang sama menunjukkan perbedaan yang nyata $(\mathrm{P}<0,05)$.

Tabel 6. Lingkar dada sapi (cm) di tiga ketinggian tempat yang berbeda di Lampung

\begin{tabular}{lcccccc}
\hline Bangsa Sapi & $\mathrm{n}$ & Lampung Tengah & $\mathrm{n}$ & Pesawaran & $\mathrm{n}$ & Lampung Barat \\
\hline Musim Hujan & & & & & & \\
Sapi bali & 13 & $149,31 \pm 15,13^{\mathrm{a}}$ & 25 & $136,82 \pm 12,46^{\mathrm{a}}$ & 3 & $150,33 \pm 9,71^{\mathrm{a}}$ \\
Peranakan ongole & 14 & $156,14 \pm 8,67^{\mathrm{a}}$ & 27 & $156,28 \pm 9,01^{\mathrm{a}}$ & 28 & $156,50 \pm 8,88^{\mathrm{a}}$ \\
Peranakan Limousin & 8 & $165,13 \pm 10,12^{\mathrm{a}}$ & 5 & $160,00 \pm 9,62^{\mathrm{a}}$ & 14 & $162,14 \pm 12,90^{\mathrm{a}}$ \\
Peranakan Simental & 7 & $162,29 \pm 12,7 \mathrm{a}^{\mathrm{b}}$ & 3 & $144,67 \pm 6,81^{\mathrm{b}}$ & 6 & $170,90 \pm 21,05^{\mathrm{a}}$ \\
\hline Musim Kemarau & & & & & & \\
Sapi bali & 13 & $151,15 \pm 11,77^{\mathrm{a}}$ & 25 & $134,88 \pm 13,34^{\mathrm{b}}$ & 3 & $151,33 \pm 9,02^{\mathrm{a}}$ \\
Peranakan ongole & 14 & $159,79 \pm 5.66^{\mathrm{a}}$ & 27 & $160,33 \pm 10,21^{\mathrm{a}}$ & 28 & $157,36 \pm 7,09^{\mathrm{a}}$ \\
Peranakan Limousin & 8 & $169,75 \pm 14,62^{\mathrm{a}}$ & 5 & $161,20 \pm 17,22^{\mathrm{a}}$ & 14 & $170,29 \pm 13,54^{\mathrm{a}}$ \\
Peranakan Simental & 7 & $163,00 \pm 13,37^{\mathrm{a}}$ & 3 & $151,00 \pm 9,64^{\mathrm{a}}$ & 6 & $162,20 \pm 13,88^{\mathrm{a}}$ \\
\hline
\end{tabular}

Keterangan: Superskrip huruf yang berbeda pada baris yang sama menunjukkan perbedaan yang nyata $(\mathrm{P}<0,05)$.

bobot badan (BB) dan pakan tambahan sebanyak $1-2 \%$ dari BB.

\section{Lingkar Dada}

Lingkar dada masing-masing bangsa sapi berikut rataannya, disajikan pada Tabel 6 untuk musim hujan dan musim kemarau. Hasil analisis terhadap rataan lingkar dada pada kedua musim menunjukkan hasil yang sama dengan tinggi badan.

Ketinggian tempat hanya memengaruhi $(\mathrm{P}<0,05)$ lingkar dada sapi peranakan simental pada musim hujan yaitu lingkar dada sapi di Pesawaran sama dengan di Lampung Tengah tetapi lebih kecil dibandingkan lingkar dada di Lampung Barat. Hasil ini menunjukkan bahwa kelembapan yang tinggi di Pesawaran yaitu
$81,43 \pm 3,66$ memengaruhi lingkar dada. Kelembapan yang tinggi bisa meningkatkatkan heat stress pada sapi (Mader et al. 2006). Kelembapan dapat meningkatkan tekanan uap dan menghambat evaporasi kulit tubuh dalam proses pelepasan panas tubuh melalui keringat.

Stess akibat kelembapan hanya memengaruhi pertumbuhan lingkar dada sapi peranakan simental, sedangkan tinggi badan tidak terpengaruh karena pertumbuhan tinggi badan sudah tercapai terlebih dahulu. Pertumbuhan tinggi badan terjadi lebih dahulu baru kemudian pertumbuhan lingkar dada seperti hasil penelitian Syawal et al. (2013) yang melaporkan bahwa urutan pertumbuhan dimensi tubuh berdasarkan analisis Gomperzt 
ialah tinggi pundak, lebar dada, lingkar dada, dan terakhir panjang badan.

Ketinggian tempat hanya memengaruhi lingkar dada sapi bali pada musim kemarau. Lingkar dada sapi bali di Pesawaran lebih kecil $(\mathrm{P}>0,05)$ dibandingkan dengan kedua daerah lainnya. Jumlah pakan yang lebih sedikit $(39,45$ kg) di Pesawaran dibanding kedua daerah lainnya ternyata berpengaruh terhadap pertumbuhan daging dan deposisi lemak.

Parameter tubuh ternak yaitu tinggi badan dan lingkar dada pada kedua musim menunjukkan bahwa sapi bali cocok dipelihara di Kabupaten Lampung Tengah. Sapi PO cocok dikembangkan pada ketiga ketinggian. Sapi peranakan limousin bisa dikembangkan di Lampung Tengah dan Pesawaran, sapi peranakan simental cocok dipelihara di Lampung Tengah dan Lampung Barat.

\section{Body Condition Score (BCS)}

Nilai BCS masing-masing bangsa sapi dapat dilihat pada Tabel 7 untuk musim hujan dan musim kemarau. Ketinggian tempat memengaruhi $(\mathrm{P}<0,05) \mathrm{BCS}$ sapi $\mathrm{PO}$ dan peranakan limousin pada musim hujan serta sapi bali dan PO pada musim kemarau.

Body Condition Score sapi PO yang rendah di Pesawaran pada musim hujan disebabkan kelembapan yang tinggi pada daerah tersebut. Energi yang diperoleh dipakai untuk pertumbuhan tinggi badan dan lingkar dada namun belum cukup untuk penimbunan lemak. Sebaliknya pada musim kemarau BCS sapi PO di Pesawaran lebih tinggi dibandingkan
Lampung Tengah. Hal ini menunjukkan bahwa berdasarkan BCS sapi PO bisa beradaptasi dengan baik pada kedua musim hanya di Lampung Barat.

Sapi peranakan limousin pada musim hujan di Pesawaran mempunyai BCS yang rendah, karena daerah tersebut mempunyai kelembapan udara yang tinggi yaitu 81,43. Kelembapan udara yang tinggi terutama di dalam kandang (> $82 \%$ ) berpotensi untuk meningkatkan kesulitas sapi silangan terutama sapi yang genotip Bos taurus-nya sampai $75 \%$, dalam membuang produksi panas tubuhnya (Aryogi et al., 2013).

Berdasarkan hasil penilaian BCS musim kemarau pada penelitian ini, menunjukkan bahwa sapi bali tidak cocok dipelihara di Lampung Barat. Ditunjukkan dengan nilai BCS yang lebih rendah dibandingkan kedua daerah lainnya tetapi mempunyai tinggi badan dan lingkar dada yang sama. Nilai BCS di Lampung Tengah dan Pesawaran baik musim hujan maupun kemarau yang paling tinggi disebabkan sapi ini memiliki beberapa keunggulan antara lain memiliki tingkat adaptasi terhadap lingkungan dengan suhu udara yang cukup tinggi. Seperti dijelaskan oleh Supriyantono et al. (2008) bahwa sapi bali merupakan plasma nutfah yang memiliki keunggulan spesifik di antaranya tahan pada kondisi lingkungan tropis dan pakan jelek, mempunyai sifat reproduksi dan kualitas karkas sangat baik serta mempunyai fertilitas yang tinggi.

Sapi bali di Pesawaran dan sapi peranakan limousin di Lampung Barat mempunyai

Tabel 7. Body Condition Score (BCS) sapi di tiga ketinggian tempat yang berbeda

\begin{tabular}{lcccccc}
\hline Bangsa Sapi & $\mathrm{n}$ & Lampung Tengah & $\mathrm{n}$ & Pesawaran & $\mathrm{n}$ & Lampung Barat \\
\hline Musim Hujan & & & & & & \\
Sapi bali & 13 & $3,00 \pm 0,50^{\mathrm{a}}$ & 25 & $2,68 \pm 0,54^{\mathrm{a}}$ & 3 & $2,50 \pm 0,50^{\mathrm{a}}$ \\
Peranakan ongole & 14 & $2,43 \pm 0,68^{\mathrm{a}}$ & 27 & $1,81 \pm 0,61^{\mathrm{b}}$ & 28 & $2,25 \pm 0,46^{\mathrm{a}}$ \\
Peranakan Limousin & 8 & $2,94 \pm 0,42^{\mathrm{a}}$ & 5 & $2,20 \pm 0,76^{\mathrm{b}}$ & 14 & $2,54 \pm 0,43^{\mathrm{ab}}$ \\
Peranakan Simental & 7 & $2,71 \pm 0,76^{\mathrm{a}}$ & 3 & $2,17 \pm 0,29^{\mathrm{a}}$ & 6 & $2,50 \pm 0,42^{\mathrm{a}}$ \\
\hline Musim Kemarau & & & & & & \\
Sapi bali & 13 & $2,92 \pm 0,28 \mathrm{a}^{\mathrm{b}}$ & 25 & $3,14 \pm 0,42^{\mathrm{a}}$ & 3 & $2,50 \pm 0,50^{\mathrm{b}}$ \\
Peranakan ongole & 14 & $1,93 \pm 0,43^{\mathrm{b}}$ & 27 & $2,44 \pm 0,82^{\mathrm{a}}$ & 28 & $2,32 \pm 0,51^{\mathrm{ab}}$ \\
Peranakan Limousin & 8 & $2,75 \pm 0,53^{\mathrm{a}}$ & 5 & $2,40 \pm 0,74^{\mathrm{a}}$ & 14 & $2,68 \pm 0,54^{\mathrm{a}}$ \\
Peranakan Simental & 7 & $2,86 \pm 0,38^{\mathrm{a}}$ & 3 & $2,67 \pm 1,04^{\mathrm{a}}$ & 6 & $2,75 \pm 0,65_{\mathrm{a}}$ \\
\hline
\end{tabular}

Keterangan : Superskrip huruf yang berbeda pada baris yang sama menunjukkan perbedaan yang nyata $(\mathrm{P}<0,05)$. 
penimbunan lemak yang bagus karena dengan tinggi badan yang rendah dan lingkar dada yang sama namun memiliki BCS yang tinggi. Hal ini menunjukkan masih terjadinya pertumbuhan bagian pinggang dan bagian pantat. Bagian tubuh yang paling lambat bertumbuh adalah bagian pinggang (loin) dan urutan laju pertumbuhan sapi betina adalah lebar kepala, lebar kemudi, lebar leher, lebar dada dan terakhir lebar pantat (Eka et al., 2014).

\section{SIMPULAN}

Dari hasil penelitian ini dapat disimpulkan bahwa berdasarkan ukuran tubuh (tinggi dan lingkar dada) serta BCS, sapi bali cocok dikembangkan di daerah dengan ketinggian 0200 mdpl. Sapi PO mempunyai ukuran tubuh sama pada ketiga ketinggian tempat namun BCS terbaiknya di ketinggian 400-500 mdpl. Sapi peranakan limousin ternyata penampilan produksi terbaiknya baik musim hujan maupun musim kemarau di ketinggian 0-200 mdpl. Sementara sapi peranakan simental cocok dikembangkan di daerah dengan ketinggian 0200 mdpl dan 400-500 mdpl.

\section{SARAN}

Perlu dilakukan penelitian tentang penampilan produksi keempat bangsa sapi (sapi bali, sapi peranakan ongole, sapi peranakan limousin, dan sapi peranakan simental) pada ketinggian 200-400 mdpl.

\section{UCAPAN TERIMA KASIH}

Terima kasih kepada Badan Penelitian dan Pengembangan Pertanian, Kementrian Pertanian yang telah memberikan bantuan dana penelitian sehingga penelitian ini bisa diselesaikan. Terima kasih pula kepada Pemerintah Daerah Kabupaten Lampung Tengah, Kabupaten Pesawaran, dan Kabupaten Lampung Barat melalui Dinas Peternakan, Perikanan dan Kelautan yang telah memfasilitasi pelaksanaan penelitian ini.

\section{DAFTAR PUSTAKA}

Arango J, Cundiff LV, Vleck LDV. 2002. Breed comparisons of Angus, Charolais, Hereford,Jersey, Limousin, Simmental, and South Devon forweight, weight adjusted for body condition score, height, and body condition score of cows. J Anim Sci 80: 3123-3132

Aryogi, Baliarti E, Sumadi, Kustono. 2013. Pengaruh genotip bos taurus terhadap performans fisiologi dan reproduksi sapi silangan Simpo dan Limpo induk di dataran rendah. Dalam: Purwantari ND, Saepulloh M, Iskandar S, Anggraeni A, Ginting SP, Priyanti A, Wiedosari E, Yulistiani D, Inounu I, Bahri S, Puastuti W (Editor). Inovasi Teknologi Peternakan dan Veteriner Berbasis Sumber Daya Lokal yang Adaptif dan Mitigatif terhadap Perubahan Iklim; 2013 September 3-5. Bogor, Indonesia. Jakarta (ID): @IAARD Press. Hlm 41-48.

Astuti M, Hardjosubroto W, Sunardi Bintara S. 2002. Livestock breeding and reproduction in Indonesia: past and future. Invited Paper in the 3 th ISTAP. Faculty of Animal Science, Gadjah Mada University. Yogyakarta. Universitas Gadjah Mada.

BPS/Badan Pusat Statistik. 2011. Pendataan Sapi Potong, Sapi Perah dan Kerbau 2011 (PSPK 2011) Provinsi Lampung. Jakarta. BPS dan Direktorat Jenderal Peternakan dan Kesehatan Hewan.

BPS/Badan Pusat Statistik Provinsi Lampung. 2015. Lampung Dalam Angka 2015, Lampung in figures. Bandar Lampung. BPS dan Badan Perencanaan Pembangunan Daerah Provinsi Lampung.

Direktorat Jendral Peternakan, 2010. Petunjuk Praktik Pengukuran Sapi Potong. Jakarta. Departemen Pertanian Republik Indonesia.

Direktorat Jendral Peternakan dan Kesehatan Hewan. 2015. Statistik Peternakan dan Kesehatan Hewan 2015. Jakarta. Kementrian Pertanian. 
Eka Y, Sampurna IP, Nindhia TS. 2014. Pertumbuhan dimensi lebar tubuh pedet sapi bali. Indonesia Medicus Veterinus 3(3): 230-236.

Hadi PU, Ilham N. 2002. Problem dan prospek pengembangan usaha pembibitan sapi potong di Indonesia. J Litbang Pertanian 21(4):148-157.

Haryoko I, Suparman P. 2009. Evaluation of carcass production of po cattle based on heart girth measurement, body condition score and slaughter weight. Animal Production 11(1): 2833

Ige AO, Adedeji TA, Ojedapo LO, Obafemi SO, Ariyo OO. 2015. Linear body measurement relationship in white fulani cattle in derived savannah zone of Nigeria. Journal of Biology, Agriculture and Healthcare 5(15): 1-6.

Mader TL, Davis MS, Brown-Brandl T. 2006. Enviromental factors influencing heat stress in feedlot cattle. J Anim Sci 84: 712719.

Mursa. 2011. ILT Ternak. ILT [Internet]. [diacu 14 Nopember 2014]. Tersedia pada http:// ibu-mursa.blogspot.com/2011/12/iltternak.html

Ni'am HUM, Purnomoadi A, Dartosukarno S. 2012. Hubungan Antara Ukuran-Ukuran Tubuh Dengan Bobot Badan Sapi Bali Betina Pada Berbagai Kelompok Umur. Animal Agriculture Journal 1(1): 541-556.

Nuriyasa IM, Dewi GAMK, Budiari NLG. 2015. Indeks kelembaban suhu dan respon fisiologi sapi bali yang dipelihara secara feed lot pada ketinggian berbeda. Majalah Ilmiah Peternakan 18(1): 5-10.

Paputungan U, Hakim L, Ciptadi G, Lapian HFN. 2013. The estimation accuracy of live weight from metric body measurements in ongole grade cows. J Indonesian Trop Anim Agric 38(3): 149-155.

Putra BW, Fuah AM, Nuraini H, Priyanto R. 2016. Penerapan teknik citra digital sebagai metode pengukuran morfometrik ternak pada sapi bali dan peranakan ongole. Jurnal Ilmu Pertanian Indonesia 21(1): 63-68.
Rutter L, Engstrom D, Hand R. 2000. Body condition : Implications for managing beef cows [internet]. [diacu 1 Juni 2015]. Tersedia pada : http://www1.agric.gov.ab.ca/ $\$$ departemen/deptdocs.nsf/all/ agdex3450?opendocument.

Sawanon S, Boonsaen P, Innuruk P. 2011. Body measurements of male kamphaengsaen beef cattle as parameters for estimation of live weight. Kasetsart J (Nat Sci) 45: 428-434

Steel RGD, Torrie JH. 1993. Prinsip danProsedur Statistika . $4^{\text {th }}$ Ed. Terjemahan: B. Sumantri. Jakarta. PT Gramedia Pustaka Utama. Hlm. 144

Sugama IN, Budiari, NLG. 2012. Pemanfaatan jerami padi sebagai pakan alternatif untuk sapi bali dara. Majalah Ilmiah Peternakan 15(1): 21-25.

Supriyantono A, Hakim L, Suyadi, Ismudiono. 2008. Performansi sapi bali pada tiga daerah di Provinsi Bali. Berk Penel Hayati 13: $147-152$.

Suretno ND, Purwanto BP, Priyanto R, Supriyatna I. 2016. Physiological Status of Four Breed Cattles On Some Different Altitudes In Lampung Province. Internasional Journal of Sciences: Basic and Applied Research (IJBAR) 26(1): 384-394.

Syawal, S, Purwanto, BP, Permana, IG. 2013. Studi hubungan respon ukuran tubuh dan pemberian pakan terhadap pertumbuhan sapi pedet dan dara pada lokasi yang berbeda. Jurnal Ilmu Ternak dan Veteriner 2(3): 175-188.

Trifena, Budisatria IGS, Hartatik T. 2011. Perubahan Fenotip Sapi Peranakan Ongole, Simpo, dan Limpo pada Keturunan Pertama dan Keturunan Kedua (Backcross). Buletin Peternakan 35(1): 11-16

Ulatus Z, Saatci M, Ozluturk A. 2001. Prediction of body weight from body measurements in East Anatolian Red calves. J Agri College of Ataturk University 26: 61-65. 